\title{
Tal como éramos
}

Ángeles Mora

Igual que hace treinta años

Pere Rovira

Nos encontramos

después de muchos años.

Hubo alegría

y ese cariño viejo que de pronto

nos sorprendió como un regalo

al comprobar que nunca se había ido.

Regresa el tiempo, o eso parece,

abriendo pozos

sin fondo,

como uno siempre vuelve

a aquel lugar de la memoria

donde la claridad deslumbra

como si fuera hoy.

No se borran las huellas que dejaron

las horas compartidas.

Duele, si acaso,

no haberlas exprimido más

al son de los minutos,

de los sueños

que no quisimos arrancarle

al reloj o a la noche. 
Sólo sé que fue ayer,

un ayer muy lejano,

tanto, que quizá pueda parecer

que es ahora mismo.

Granada y la poesía.

Mis versos primerizos

despeñándose bravos

ante vosotros,

poetas catalanes

que bajasteis al sur

a plantar vuestras voces nuevas

en los sembrados nuestros

$y$ arańarnos con rayos de luz viva,

en tanto que os hería

la sed de otras preguntas.

Hora es de celebrarnos todos juntos,

los que estamos,

los que ya se nos fueron,

sentirnos

otra vez todos juntos,

mientras quema despacio y rueda

la brisa de aquel sueño,

con amapolas rojas en el trigo,

esas que -dice Joan-

hoy ya desaparecen...

Pero siguen temblando

aquí en el corazón

como cartas marcadas.

Deja que alcemos nuestras copas

colmadas de palabras

para brindar por la amistad.

Deja que las rompamos luego

chocando con la tuya,

Pere, amigo.

Julio, 2018 